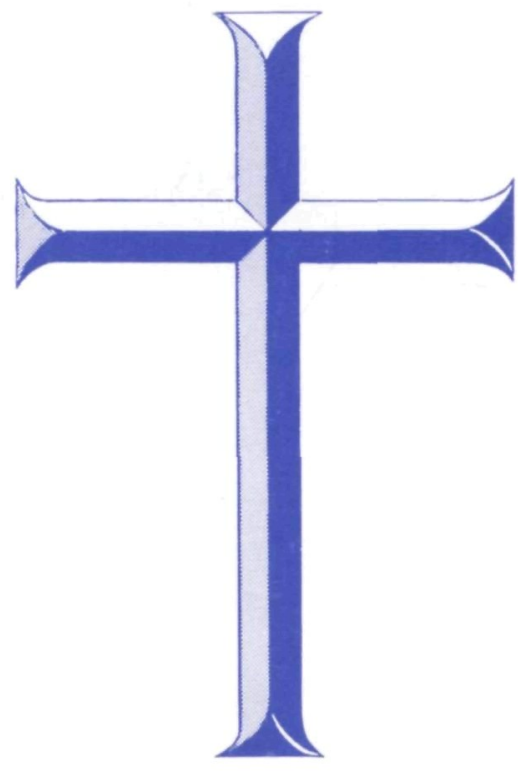

SCOTTISH JOURNAL OF

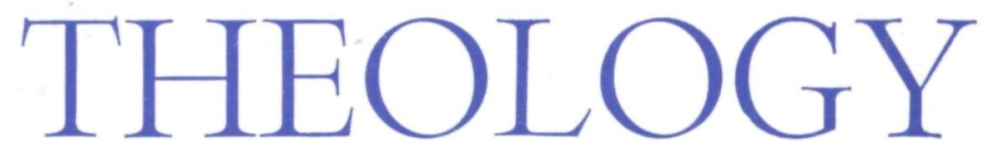

T \& T GLARK

E D I NBUR GH 


\section{SCOTTISH JOURNAL OF THEOLOGY}

EDITORS

Rev. Prof. Alasdair I. C. Heron (University of Erlangen)

REv. Dr. IaIn R. TORrance (University of Birmingham)

North America

Rev. Prof. Alan E. Lewis (Austin Presbyterian Theological Seminary)

DIRECTORS

Rev. ANDRew F. Anderson (Edinburgh)

Dr. Geoffrey F. Green (Edinburgh), Publisher

Rev. Prof. Alasdair I. C. Heron (Erlangen), Editor

Rev. Prof. Alan E. Lewis (Austin), Editor

Rev. Gerald C. Moule (Moffat), Secretary and Treasurer

ReV. Prof. J. K. S. ReID (Edinburgh)

Very Rev. Prof. Thomas F. Torrance (Edinburgh)

Dr. Thomas S. TORRance (Aberdeen), Chairman

Rev. Dr. IaIn R. Torrance (Birmingham), Editor

CONSULTING EDITORS

Very Rev. Prof. R. S. Barbour (Pitlochry)

Very Rev. Prof. Robert Davidson (Glasgow)

Prof. David F. FORD (Cambridge)

Rev. Prof. Duncan B. Forrester (Edinburgh)

REV. DR. J. Houston (Glasgow)

DR. PAul Joyce (Birmingham)

Rev. Prof. W. Peter Stephens (Aberdeen)

\section{EDITORIAL POLICY}

A quarterly Journal of Theological Inquiry and Reconstruction edited and published in Scotland, Scottish fournal of Theology is a broadly based international and ecumenical publication aimed at establishing modern theology on a sound scientific basis which commands wide agreement. It publishes contributions of major theological and philosophical interest from the world's leading scholars and also carries articles on biblical and applied theology intended to help the preacher and teacher. It seeks to meet the needs of university, seminary and church through constant dialogue with sciences other than theology and by engaging in current issues, both by original thinking and by extensive reviewing of biblical and theological literature.

Since it was first issued as a quarterly in 1948 to provide a forum for critical inquiry into the historic foundations of theology and fresh thinking for the future, Scottish Fournal of Theology has come to play a considerable role in world-wide theological discussion and renewal, and has stimulated an increasing flow of important and creative theological work.

\section{PERMISSIONS}

For permission to reproduce material from Scottish fournal of Theology please apply to T\&T Clark, 59 George Street, Edinburgh EH2 2LQ, U.K. 


\section{SCOTTISH JOURNAL OF THEOLOGY}

\section{Volume Forly-four}

1991 


\title{
SCOTTISH JOURNAL OF
}

\section{THEOLOGY}

Volume Forly-four

1991

\author{
EDITORS EMERITI \\ T. F. TORRANCE \\ M.B.E., F.B.A., F.R.S.E., \\ Dr Theol., D. LiTT., D.D., D. TheOl., Dr TheOl., D.SC. \\ J. K. S. REID \\ C.B.E., T.D., D.D.
}

EDITORS

A. 1. C. HERON, M.A., B.D., DR Theol.

I. R. Torrance, M.A., B.D., D. PHIL.

EDITOR IN AMERICA

Alan E. Lewts, M.A., B.D., Th.D.

EDITORIAL SECRETARY

ANDREW F. ANDERSON, M.A., B.D.

T\&TCLARK

EDINBURGH

1991 


\section{T\&T CLARK LTD 59 GEORGE STREET EDINBURGH EH2 2LQ SCOTLAND}

Copyright $\odot$ T\&T Clark Ltd., 1991

All rights reserved. No part of this publication may be reproduced, stored in a retrieval system, or transmitted, in any form or by any means, electronic, mechanical, photocopying, recording or otherwise, without the prior permission of T\&T Clark.

ISBN 03369306

Typeset by Trinity Typesetting, Edinburgh

Printed and bound in Great Britain by Bell \& Bain Ltd, Glasgow 


\section{CONTENTS}

\section{NUMBER 1}

Metaphorical Non-Sequitur?

by Professor F. SonTAG

Models for Scripture

by The Rev. Dr J. GoldingaY

The Laity - Bishop's pawn? Ignatius of Antioch on the Obedient Christian by The Rev. Dr Alvyn Petterson

A Kind of Liturgical ARCIC? The Ecumenical Potential of the four Eucharistic Prayers of Rite $A$ in

The Alternative Service Book 1980

by The Rev. David J. KENNEDY

Mr Sanders' Pharisees and Minc: A Response to

E. P. Sanders, Jewish Law from Jesus to the Mishnah

by Professor Jacob NeUSNER

\section{REVIEWS}

BEECK: God Encountered, A Contemporary

Catholic Systematic Theology, Volume

One: Understanding the Christian Faith

Poux: On the Way to God: An Exploration into the Theology of Wolfhart

Pannenberg

SCHADEL AND SAUR (Eds.): Bibliotheca

Trinitariorum: Internationale Bibliographie

trinitärischer Literatur/International

Bibliography of Trinitarian Literature

Volume 1

Carvo: Creation and Scientific Explanation

Yu: Being and Relation: A Theological Critique of Western Dualism and

Individualism

102

PHIL.JPS: Faith After Foundationalism 103

GABREL DALY. Creation and Redemption 106

The Intomational Theological Commentary Series

hasiltoN: Inheriting the Land (Joshua)

ANDERSON: Signs and Wonders (Daniel)

rNIGHT: Servant Theology (Isaiah 40-55)

stuhLmUelex Rebuilding with Hope

(Haggai \& Zechariah)

INIGHT AND COLX: Revelation of God (The

Song of Songs \& Jonah) cowav: From Eden to Babel (Cenesis 1-11) brueccemann: To Pluck Up, To Tear Down

(Jeremiah 1-25)

ROCERSON AND DAVIES: The Old Testament

World

NEUSNER: The Incarnation of Cod: the

Character of Divinity in Formative Judaism

110

CROUZEL: Origen

112

GanoczY: The Young Calvin $\quad 116$

wALLACE: Calvin, Geneva and the

Reformation

116

Prodl: The Papal Prince. One body two souls: the papal monarchy in early modern

Europe

JENSON: America's Theologian: A Recommendation of Jonathan Edwards 127 MCaDoo: The Eucharistic Theology of Jeremy

Taylor Today 129 THOMPSON: A Bibliography of Christian Worship

suluran: The Church We Believe In 193 cox: The Silencing of Leonardo Boff: The Vatican and the Future of World Christianicy 135 BIRCH AND RASMUSSEN: Bible and Ethics in the Christian Life 137 


\section{CONTENTS}

\section{NUMBER 2}

'Creatio ex nihilo': A Context for the Emergence of the Christian Doctrine of Creation

by Professor Frances Young

Nicodemus

by Dr Michael Goulder

The Intermediate State in the New Testament

by The Rev. Dr OsEI-Bonsu

Two Early Reformed Catechisms, The Threefold Office and the

Shape of Karl Barth's Christology

by The Rev.Pun Butrin

John William Colenso: Pioneer in the Quest for an Authentic

African Christianity
by Professor EPHRAIM MosothoANE

\section{REVIEWS}

BIGGAR (ed.): Reckoning with Barth: Essays in Commemoration of the Centenary of Karl

Barth's Birth THOMPSON and PARK (Eds.): Theology Beyond

Christendom: Essays on the Centenary of the

Birth of Karl Barth

muxanson: Christian Ethics in Health Care

STANNARD: Grounds for Reasonable Belief

$\begin{array}{ll} & 240 \\ \text { CASSIRER: Grace and Law } & 242\end{array}$

SANDERs and DAvEs: Studying the Synoptic

Cospels

couWEns: Kierkegaard's Dialectic of the

Imagination

HERBERT and MACNAMARA: Irish Biblical Apocrypha: Selected Texts in Translation

scorcie: A Call for Continuity. The Theological

Contribution of James Orr

HOOKER: Of the Laws of Ecclesiastical Polity.

Preface, Book 1, Book 2

LaChman: The Marrow Controversy 1718-1723.

An Historical and Theological Analysis 248 RAHNER: Theological Investigations Vol. XXI

Warner: Philosophical Finesse

MASON: Philosophical Rhetoric ryoncsuk: Dialectic of Salvation: Issues in Theology of Liberation 255 carroll: A Pilgrim God for a Pilgrim People

HILTON: The Age of Atonement: the Influence of Evangelicalism on Social and Economic Thoughe 1795-1865 258 DUKE and STREETMAN (Eds.): Barth and SCHLEIERMACHER: Beyond the Impasse? 260 WANRIGrr (Ed.): Keeping the Faith. Essays to Mark the Centenary of Lux Mundi 264 KTIELSON: Luther the Reformer $\quad 266$ Bauckham Moltmann Messianic Theology in the Making 267 cuprt: The New Christian Ethics 269 Gray (Ed.): The Word in Season: Essays by Members of the Joint Liturgical Group on the use of the Bible in Liturgy $\quad 270$ LAWLER: Symbol and Sacrament: a Contemporary Sacramental Theology 271 LOCHHEAD: The Dialogical Imperative. a Christian Reflection on InterFaith Encounter

REEs: Pelagius. A Reluctant Heretic 273 MEDhURST and morer. Church and Politics in a

Secular Age 278 Horstmann Software: Chiwriter [Version 3.16] Greek, Hebrew Arabic Edition 280 


\section{CONTENTS}

\section{NUMBER 3}

\section{Reflections on the Sermon on the Mount}

by Professor W. D. Davies and Dr Dale C. Allison, Jr.

Christianity as Insurrection

by Professor P. MATHEson

God, Man and Nature: The Problem of Creation in

Cartesian Thought

by Professor EdWARd B. Davis

Modern Trinitarian Perspectives

by The Very Reverend Professor JoHn THOMPSON

'Like an Ever-rolling Stream': Some Recent Commentaries

on Romans

by Dr A. J. M. WEDDERBURN

\section{REVIEWS}

PICKRRNa: Anglo Catholicism: A study in religious aimbiguity

VAN IERSEL Reading Mark

PARKER: Philip Melanchthon: Paul's Letter to the Colossians

MARTIN: James [Word Biblical

Commentary, 48]

Avis: Eros and the Sacred

BYRNE: Natural Religion and the Nature of Religion: The Legacy of Deism STEVENSON: Accept this Offering: The Eucharist as Sacrifice Today kUNC AND TRuCr.Paradigm Change in Theology

MEEks: Cod the Economist: The Doctrine of Cod and Political Economy

LNDARs: Law and Religion: Essays on the Place of Law in Isracl and Early Christianity

Huches: The True Image: The Origin and Destiny of Man in Christ COOTE AND ORD: The Bible's First History 403 whrmore: Ethics in the Nuclear Age MOESSNER: Lord of the Banquet: The Literary and Theological Significance of the Lukan Travel Narrative

LEHMANN AND PANNENBERC: The Condemnations of the Reformation Era. Do they still divide?

LENHARD: L'Evangile et L'Eglise chez Luther

Avis: Anglicanism and the Christian Church: Theological Resources in Historical Perspective

Bexer: Paul the Apostle: The Triumph of Cod in Life and Thought runcsburr. Conflict in Mark: Jesus, Authorities, Disciples

ELIS AND MADURO: The Funte of Liberation Theology. Essays in Honour of Gustavo Gutiérrez

Gammig: Holiness in Lsrael avis: The Threshold of Theology
418 
viii

\section{CONTENTS}

NUMBER 4

Parables, Secrecy and Eschatology in Mark's Gospel

by The Reverend C. L. MEARNS

Gen. 15.6 and Early Christian Struggles Over Election

by Professor D. Dixon Sutherland

The Puritan Roots of American Universalism

by Mr K. R. MORRIS

Reform, Reconstruction, Reaction: The Social Vision

of Scottish Presbyterianism c. 1830-c. 1930

by Professor S. J. Brown

Moltmann's Messianic Christology

by Dr RichaRd J. BAUCKHAM

\section{REVIEWS}

macquarrie: Jesus Christ in Modern Thought

553

Thatcher: Truly a Person, Truly Cod: A Post-

Mythical View of Jesus

534

MEBbLETHWATtE: The Ocean of Truth: A

Defense of Objective Theism $\quad 535$

HODGSON: God in History: Shapes of Freedom

538

O'HANLON: The Immutability of God in the

Theology of Hans Urs von Balthasar 538 bauckram: The Bible in Politics. How to Read the Bible Politically
COCCNS AND HOULDEN: A Dictionary of

Biblical Interpretation 541 younc: The Art of Performance: Towards a

Theology of Holy Scripture $\quad 542$ Day. Gender and Difference in Ancient Israel 544

ANDERson: 2 Samuel (Word Biblical Commentary 11)

Books Received 545

Index of Authors

Index of Books 